\title{
Angiomyofibroblastoma of the retrorectal region: a case report
}

\section{Retrorektal bölge anjiomyofibroblastomu: Olgu Sunumu}

\author{
Hülya Ayık Aydın ${ }^{1}$, Alaattin Aydın², Muhittin Yaprak², Zeynep Bayramoğlu³, Elif İnanç \\ Gürer $^{3}$, Tayup Şimşek ${ }^{1}$ \\ ${ }^{1}$ Akdeniz Üniversitesi Kadın Hastalıkları Ve Doğum Jinekolojik Onkoloji Cerrahisi \\ ${ }^{2}$ Akdeniz Üniversitesi Genel Cerrahi Ana Bilim Dalı \\ ${ }^{3}$ Akdeniz Üniversitesi Patoloji Anabilim Dalı
}

Dergiye Ulaşma Tarihi: 14.09.2017 Dergiye Kabul Tarihi: 08.10.2017 Doi: 10.5505/aot.2017.65365

\section{ÖZET}

Anjiomyofibroblastoma nadir benign subkutanöz mezenkimal lezyondur. Sıklıkla reproduktif yaş ve erken menopozdaki kadınlarda vulvovajinal bölgede tanımlanır, diğer kadın ürogenital traktus alanlarında da tanımlanmıştır; erkek inguinoskrotal bölgede de tanımlanmaktadır.Bartolin gland kisti ya da lipoma ile klinik olarak karışabiliir. 44 yaşında bayan hasta Akdeniz Üniversitesi Tıp Fakültesi Jinekolojik Onkoloji bölümüne Aralık 2016 tarihinde başvurdu. 8 aydır devam eden pelvik ağrı şikayeti mevcuttu. Palpabl, sol lateral vajinal duvara protrude solid hassas olmayan lezyon gözlendi. Bimanuel muayenede retrorektal bölgede vajina ile ilişkili 8x7 cm mobil kitle gözlendi. Hasta Ocak 2017 tarihinde genel cerrahi bölümü ile birlikte opere edildi. Ameliyat sonrası dönemde problem yaşamayan hasta kontrol ve takip önerilerek hastaneden taburcu edildi. Spesimenin patolojik incelemesinde opak beyaz 7x $6 \mathrm{~cm}$ solid kitle gözlendi, kitlenin mikroskopik incelemesinde iyi sinırlı spindle ve epiteloid hücre içeren lezyon gözlendi. Histolojik bulgulara dayanılarak anjiomyofibroblastom tanısı konuldu. Yakın postoperatif takip planlanan hastanın ameliyat sonrası 7. ay kontrolünde anormal bulguya rastlanilmadi.

Özet olarak, retrorektal bölge anjiomyofibroblastomu oldukça nadir ve tanısı zor bir tümördür. AMFB'nin benign davranışı, nadir lokal rekürrensi nedeniyle diğer neoplazileri dışlamak ve histolojik özelliklere dayanarak doğru tanıyı koymak önemlidir.

Anahtar Kelimeler: Anjiomiyofibroblastom, mezenkimal tümör, alt genital traktus

\begin{abstract}
Angiomyofibroblastoma (AMFB) is a rare benign subcutaneous mesenchymal lesion. AMFB is mostly described in the vulvovaginal region with occasional cases reported in other female urogenital tract sites in women of reproductive age and early menopause, and in the male inguinoscrotal region. AMFB can clinically be misdiagnosed for Bartholin's gland cyst or lipoma. A. 44-year-old female patient admitted firstly in December 2016 to gynecologic oncology department of Akdeniz University Medical Faculty. She had complaints of pelvic pain for the previous 8 months. A palpable, nontender solid mass lesion protruding to the left lateral wall of the vagina was observed. Bimanual examination detected a mobile mass measuring $8 \mathrm{x} 7 \mathrm{~cm}$ in the retrorectal region, communicating with vagina. The patient was operated in January 2017 in collaboration with department of general surgery. Her postoperative period was uneventful, and she was discharged and future control visit was arrange. Surgical specimen appeared as an opalescent-white solid mass measuring 7 × $6 \mathrm{~cm}$.Its microscopic examination revealed a well-circumscribed lesion containing spindle, and epitheloid cells. Based on histological findings, the diagnosis of angiomyofibroblastoma was made. Close postoperative follow-up was decided for the patient. Postoperative 7. month gynecologic controls of the patient did not reveal any pathologic finding. In summary, AMFB of the retrorectal region is extremely rare and is diagnostically challenging. Because of the benign behavior of AMFB with rare local recurrence, excluding other neoplasms and making the accurate diagnosis based on histological features is important.
\end{abstract}

Keywords: Angiomyofibroblastoma, mesenchymal tumor, lower genital tract. 


\section{Introduction}

Angiomyofibroblastoma (AMFB) is a rare benign subcutaneous mesenchymal lesion first described in 1992 (1). Term "angiomyofibroblastoma" is established on 2 parts of the tumor: prominent vasculature comprising plentiful small/medium sized blood vessels, and mesenchymal cells condensed around vessels (1).

Angiomyofibroblastoma is mostly described in the vulvovaginal region with occasional cases reported in other female urogenital tract sites in women of reproductive age and early menopause, and in the male inguinoscrotal region (2).

To the best of our knowledge, this is the second reported case of AMFB (3) that arise from retrorectal region occurring in a 44-year-old woman.

\section{Case report}

A 44-year-old female patient admitted firstly in December 2016 to gynecologic oncology department of Akdeniz University Medical Faculty. She had complaints of pelvic pain for the previous 8 months. A palpable, nontender solid mass lesion protruding to the left lateral wall of the vagina was observed. Bimanual examination detected a mobile mass measuring $8 \times 7 \mathrm{~cm}$ in the retrorectal region, communicating with vagina. On pelvic magnetic resonance imaging, a mass protruding into vagina was observed. The mass appeared as a soft tissue containing heterogenous internal tissue with regular contours. On gynecological examination, normal adnexial, and cervical structures were observed without parametrial involvement.

The patient was operated in January 2017 in collaboration with department of general surgery. Sacral region was opened through mediolateral incision with the patient in the prone jack-knife position. Pelvic floor muscles were retracted to one side, the layers were dissected to get contact with the mass lesion. The mass was dissected away from the rectum, and excised with surrounding soft tissue, and a part of posterior wall of vagina. Her postoperative period was uneventful, and she was discharged and future control visit was arranged.

Surgical specimen appeared as an opalescent-white solid mass measuring 7 x $6 \mathrm{~cm}$ (Figure 1). Its microscopic examination revealed a well-circumscribed lesion containing spindle, and epitheloid cells. It contained hypo, and hypercellular areas (Figures $2 \mathrm{~A}$, and $\mathbf{B}$ ). Randomly dispersed blood vessels, and perivascular stromal cell condensations were found. Based on histological findings, the diagnosis of angiomyofibroblastoma was made. Immunohistochemical examination revealed the presence of desmin-vimentin positive stromal cells. Stromal cell was Actin and S100negative, but estrogen receptor-, and progesterone receptor- positive (Figures $3 \mathbf{A}$, and B). Blood cells were made conspicuous with smooth muscle actin. The stromal cells were kaldesmon, CD 34, ALK, S-100, CD 31, Pan CK-negative, and Ki-67 proliferation index was 5 percent.

Close postoperative follow-up was decided for the patient. Postoperative 7. month gynecologic controls of the patient did not reveal any pathologic finding.

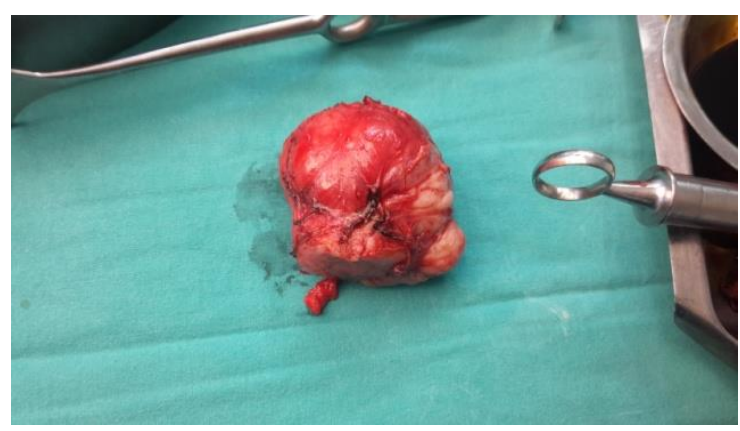

Figure 1. A solid, and pearlescent-white surgical specimen with dimensions of $7 \times 6 \mathrm{~cm}$.
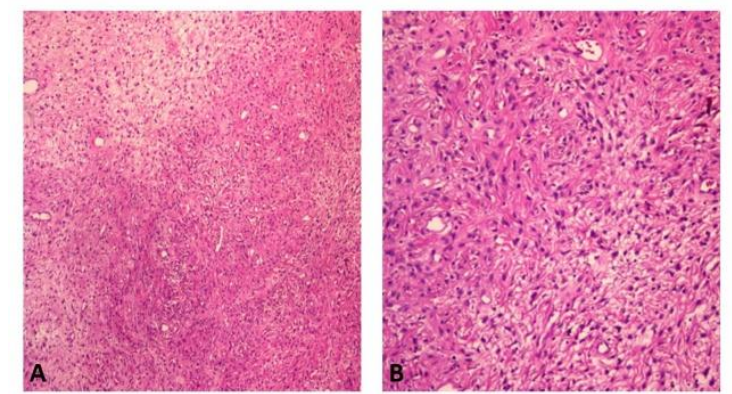

Figure 2. Angiomyofibroblastoma of vulva, admixed with small blood vessels. (H\&E stain A. x5, B. x10). hypercellular, hypocellular and myxoid areas 


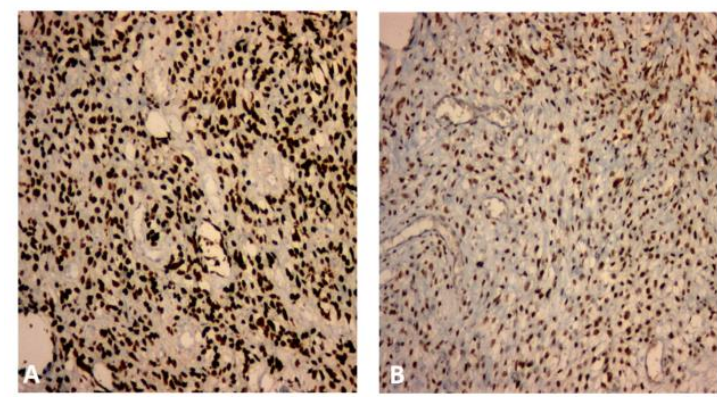

Figure 3. Nuclear immunoreactivity for A. estrogen receptor protein $(\mathrm{x} 10)$, B. progesterone receptor protein (x10).

\section{Discussion}

Angiomyofibroblastoma was became largely known by Fletcher et al., who defined 10 AMFB cases primarily involving the vulvovaginal area of middle-aged women (1). To our knowledge, just four pelvic AMFB cases have been described up to now (3-7). Table 1 reviews the main clinicopathological characteristics of reported cases. To the best of our knowledge, first time Menendez et al. reported a case of AMFB in the ischiorectal fossa sized 5.5x 4.3 2 in a 49-year-old woman (3).

The occurring mean age of the female patients is 45.8 years and somewhat slowgrowing without pain (8). It is slow growing tumor with before seeking treatment about 29 months (8). The present case was 44-year-old who had complaints of pelvic pain for the previous 8 months.

Macroscopically, a AMFB has a tanpink in color and a soft uniformity; also, wellcircumscribed however not encapsulated. Most AMFBs present as a painless, slow-growing, sharply demarcated mass ranging from 0.5 to 12 $\mathrm{cm}$ in size (9). Typically, AMFB can clinically be mistaken for a lipoma or a Bartholin's gland cyst. In the present case, the surgical specimen appeared as an opalescent-white solid mass measuring $7 \times 6 \mathrm{~cm}$.

Microscopically, abundant thin-walled blood vessels with hypocellular and hypercellular areas are the main histological findings of the tumor (10). Well-developed Golgi apparatus and prominent rough endoplasmic reticulum are the leading fibroblastic differentiation of the stromal cells. In the present case, the microscopic examination revealed a well-circumscribed lesion containing spindle, and epitheloid cells with hypo-, and hypercellular areas. Randomly dispersed blood vessels, and perivascular stromal cell condensations were found.

The immunophenotype of AMF is variable and of limited value in diagnosis (11). Conservative zones of AMFB are usually positive for desmin, vimentin, estrogen receptor and progesterone receptor. Expression of smooth muscle actin is variable. This immunophenotype intersects with further mesenchymal tumors in differential diagnosis (11). CD34 is frequently negative in AMFB, a feature beneficial in distinction from cellular angiofibroma and spindle cell lipoma, which are usually positive. S100 is just appear in lipomatous AMFB and was negative in our case. In the present case, immunohistochemical examination revealed that stromal cells were desmin, vimentin, estrogen receptor-, and progesterone receptor- positive; but actin and S100-negative. Blood cells were made conspicuous with smooth muscle actin. The stromal cells were also kaldesmon, CD 34, ALK, S-100, CD 31, Pan CK-negative, and Ki67 proliferation index was 5 percent.

Only a single case of AMFB showing malignant/sarcomatous transformation has been reported to date (12). AMFB is characteristically treated with local excision and radiation and chemotherapy play no role in the treatment. Recurrence may occur if the lesion is incompletely excised and long-term follow-up management are recommended. The present case underwent simple excision with clear margin of the lesion without any pathologic findings on the postoperative $7^{\text {th }}$ month.

\section{Conclusion}

In summary, AMFB of the retrorectal region is extremely rare and is diagnostically challenging. Because of the benign behavior of AMFB with rare local recurrence, excluding other neoplasms and making the accurate diagnosis based on histological features is important.

Conflict of interest: None 


\section{References:}

1. Fletcher CD, Tsang WY, Fisher C, Lee KC, Chan JK. Angiomyofibroblastoma of the vulva: a benign neoplasm distinct from aggressive angiomyxoma. Am J Surg pathol. 1992;6:378-82.

2. Roncati L, Pusiol T, Piscioli F, Barbolini G, Maiorana A. Undetermined cervical smear due to angiomyofibroblastoma of the cervix uteri. J Obstet Gynaecol. 2017;37(6):829-830.

3. Menendez SP, Villarejo CP, Padilla VD, Munoz AV, Gonzalez LL, Martin FJ. Angiomyofibroblastoma of the right ischiorectal fossa. Cir Cir 2010;78:448-50.

4. Quintero C, Sasken H, Houck KL, Hernandez E. Angiomyofibroblastoma of the retroperitoneum: a case report. J Reprod Med 2007;52:741-4.

5. Lim KJ, Moon JH, Yoon DY, Cha JH, Lee IJ, Min SJ. Angiomyofibroblastoma arising from the posterior perivesical space: a case report with MR findings. Korean J Radiol 2008;9:382-5.

6. Kobayashi $\mathrm{T}$, Suzuki $\mathrm{K}$, Arai $\mathrm{T}$, Sugimura $\mathrm{H}$. Angiomyofibroblastoma arising from the fallopian tube. Obstet Gynecol 1999;94:83;3-4.
7. Cetinkaya K, Al RA, Gursan N. Angiomyofibroblastoma of the vulva during pregnancy. J. Obstet Gynaecol Res 2011; 37: 1162-5

8. Nucci MR, Fletcher CD. Vulvovaginal soft tissue tumors: update and review. Histopathology. 2000;36(2):97-108.

9. Laskin WB, Fetsch JF, Mostofi FK. Angiomyofibroblastoma-like tumor of the male genital tract: analysis of 11 cases with comparison of female angiomyofibroblastoma and spindle cell lipoma. Am J Surg pathol. 1998;22:6-16.

10. Nielsen GP, Rosenberg AE, Young RH, Dickersin GR, Clement PB, Scully RE. Angiomyofibroblastoma of the vulva and vagina. Mod Pathol. 1996; 9(3):284-91.

11. McCluggage WG. Recent developments in vulvovaginal pathology. Histopathology 2009;54:156.

12. Neilsen GP, Young RH, Dickersin GR, et al. Angiomyofibroblastoma of the vulva with sarcomatous transformation "angiomyofibrosarcoma". Am J Surg Pathol 1997;21:1104-8. 